\title{
Studies of Musicology by Liliana Gherman
}

\author{
LAURA OTILIA VASILIU, Professor PhD \\ "George Enescu" National University of the Arts Iași \\ ROMANIA*
}

\begin{abstract}
Liliana Gherman (born in 1939) is a very well-known name in music criticism in Romania, the author being professor at 'George Enescu' National University of the Arts of Iași. Her writings have proven that her critical thinking is in line with the style of a whole generation of Romanian musicologists, such as Elena Zottoviceanu, Clemansa Liliana Firca, Gheorghe Firca or Grigore Constantinescu to name only a few. In her double capacity of professor of Musical Forms and musicologist-analyst, Liliana Gherman has published highly professional scientific papers, detecting modern compositional techniques and promoting contemporary Romanian creations through advanced analytical methods. The book that we review Zăbave analitice. Studii de muzicologie (Analytical Depths. Studies of Musicology) (Artes Publishing House, Iași, 2019) - comprises the first part of her work as a musicologist.
\end{abstract}

Keywords: musical analysis, musicology, music criticism, Alexandru Pașcanu, George Enescu.

The book that we are reviewing, self-pensively entitled Zăbave analitice (Analytical Depths), includes a set of musicological papers published between 1973 and 1993 by Liliana Gherman, professor at "George Enescu" National University of the Arts, which are the proof of the author's high level of professional and scientific performance. In addition to its meaningful role of restitution, the book completes the current image of the specialist Liliana Gherman, much better known as a music critic, both during her long period of uninterrupted activity of chronicler - 1966-1995 - and subsequently, by their republication in the three volumes Dimensiuni ale creației și interpretării (Dimensions of Creation and Performance) (Editura Artes, 2003; 2011).

Liliana Gherman is a distinct voice among the music critics in Iasi, Romania, due to her style and attitude, created by the mutual influence of music criticism and analytical musicology. In criticism, her main concern was objectivity, whereas in musicology, the recipient self was always present. Thus, Liliana Gherman's music reviews are a historical document which one may fully trust, whereas her study of musicology is much more than a mere compulsory academic duty, it is a fully assumed experience which sheds light and opens new paths. Whereas in the world of music criticism, she managed to

\footnotetext{
*otiliastrug@yahoo.com
} 
make herself noticed in a cultural environment where specialized publications already had a long history and a comprehensive representation (George Pascu, Mihail Cozmei, Paula Bălan, Melania Boțocan, Dora-Maria David, etc.), in the analytical universe of scientific musicology, she laid the foundations of a starting point and she created a model of thinking and research among the researchers in Iasi.

The years in which Liliana Gherman wrote her first reviews of musical analysis were also the years of development of this field in Romania, an area of musicological manifestation supported by the specialized journals of the time: Muzica, Studii de muzicologie [Music, Studies of Musicology] (București), Lucrări de muzicologie [Musicology Papers] (Cluj-Napoca), Scrieri de muzicologie [Musicology Writings] (Iași). After 1970, our national science also opened up to the transformation of the conception of musical text under the influence of French structuralism and semiology. Later on, when my generation discovered J.J. Nattiez's conception and method of analysis, we were surprised to find out that amazed that Liliana Gherman was the only one in Iasi to hold his famous book Fondements d'une sémiologie de la musique (Paris, 1975).

Her pro-active approach to the discovery of a rigorous and adequate technique for understanding music scores may also be accounted for by the influence of her masters during her education at the Bucharest Conservatory, such as Ștefan Niculescu, Aurel Stroe, Alexandru Pașcanu, Dinu Ciocan - who were all already greatly concerned with understanding musical structures and with analyzing contemporary music. Liliana Gherman contributed to the modernization of sound art thinking, together with other musicians from "George Enescu" Conservatory like Vasile Spătărelu, Anton Zeman, Sabin Păutza - young composers and teachers of the '70s. Her long history of editor of the scientific journals Scrieri de muzicologie [Musicology Writings] (1973-1986) and Artes (1995-2010) has greatly contributed to the renewal of the musicological style of musicologists in Iasi, to the ever-rigorous observance of scientific originality requirements.

The nine papers included in the book reflect the author's ever-growing hunger of knowledge. We will first refer to researches in musicology itself. Problematica analizei și formelor muzicale în scrierile lui Titus Cerne [The Issue of Musical Analysis and Forms in Titus Cerne's Writings] (1986) is a 
relevant historiographic research on the contribution of the professor from Iasi (1859-1910) to the foundation of the terminology and contents of European cult art in Romanian, through the two volumes of the Dictionary of Music, part of his extensive research work. Constantin Brăiloiu, exeget al muzicii clasice și romantice [Constantin Brăiloiu, Exegete of Classical and Romantic Music] (1993), a research elaborated by Liliana Gherman after the rich experience of chronicler, for which she was awarded the Music Criticism Award (1991), is a refined and profound review, which emphasizes Constantin Brăiloiu's exceptional hermeneutic qualities.

Her analysis of old polyphonic music in the paper entitled Motetul secolului XIII Câteva considerații asupra structurii și formeii [Motet of the $13^{\text {th }}$ Century. Some Considerations on its Structure and Form] (1976) is a surprising move from Liliana Gherman and her consecrated musicologist image. The author's profile is to be found in the process of looking for the signs of constructive thinking in the primary compositional typology.

Her admiration of and attachment to Alexandru Pașcanu, proven by the four dedicated titles, are sincerely expressed: "there is no work, regardless of size, which does not have expressive relief, just as there is no work which, following its analytical review, does not reveal different facets of his compositional mastery, a reflection of both his conscious thinking and his intuition" (Gherman, 2019, p. 119). If we have a look at the paper entitled Alexandru Pașcanu: Piesa simfonică ,In memoriam” [Alexandru Pașcanu: Symphonic Creation 'In memoriam'] (1977), we note that the author's decisions regarding form are equally based on compositional and music reception strategies. It is a very detailed analysis, as "despite the appearances, the aim was not an autopsy, but the careful observation of a musical organism in its vital manifestations" (Gherman, 2019, p. 83). On the other hand, the paper Alexandru Pașcanu: „Pro Humanitate” (1987) is absolutely enchanting due to its literary beauty, and suggestiveness of semantic interpretation.

The paper entitled Sabin Pautza: Cantata „COLUMNE” pentru cor și orchestră pe versuri de Vasile Filip [Sabin Pautza: 'COLUMNS' Cantata for Chorus and Orchestra on Lyrics by Vasile Filip] (1978) provides a model analysis that combines hermeneutic text-music relationship comments with compositional language presentation in a structuralist manner, following the detail-whole ratio.

The coherence, eloquence and originality of Enescu's dramaturgy is proven by a rigorous semiotic analysis in the paper entitled GEORGE ENESCU - o lucrare mai puțin cunoscută: Prima Sonată pentru pian și violoncel [GEORGE ENESCU - a lesser known work: the First Sonata for Piano and Cello] (1983). The stylistic specificity and harmonic technique are decoded by extremely detailed graphical representations. 
Liliana Gherman's musicology, as it is depicted in this first book of reviews, reveals several particular aspects: it is a cultural, referential musicology, it is equally methodical and reflective, and, above all, it is fundamental musicology, the research topics being either tackled for the first time, or given new meanings. These are music research values that we rediscover periodically.

\section{References}

Cozmei, M. (2010). Existențe și împliniri. Dicționar biobibliografic. Domeniul muzică [Existence and fulfillment. Bio-bibliographical dictionary. The field of music], 2nd edition. Iași: Artes.

Gherman, L. (2019). Zăbave analitice. Studii de muzicologie [Analytical Depths]. Iași: Artes.

Gherman, L. (2003; 2011). Dimensiuni ale creației și interpretării. File de cronică muzicală [Dimensions of Creation and Performance. Pages of musical criticism], vol. I, II, III. Iași: Artes.

Vasiliu, L. (2007). Muzicologia și jurnalismul. Prezența muzicii clasice în media românească de după 1989 [Musicology and journalism. The presence of classical music in the Romanian media after 1989]. Iași: Artes. 